\title{
Essential Oil of Piper Purusanum C.DC (Piperaceae) and Its Main Sesquiterpenes: Biodefensives Against Malaria and Dengue Vectors, Without Lethal Effect on Non-target Aquatic Fauna
}

André C. de Oliveira ( $\square$ andrebiologo2011@gmail.com )

Universidade Nilton Lins https://orcid.org/0000-0001-9258-3108

Rejane C. Simões

Fundação de Vigilância em Saúde do Amazonas Dra Rosemary Costa Pinto

Carlos A. P. Lima

INPA: Instituto Nacional de Pesquisas da Amazonia

Felipe M. A. da Silva

UFAM: Universidade Federal do Amazonas

Sergio M. Nunamura

INPA: Instituto Nacional de Pesquisas da Amazonia

Rosemary A. Roque

INPA: Instituto Nacional de Pesquisas da Amazonia

Wanderli P. Tadei

INPA: Instituto Nacional de Pesquisas da Amazonia

Rita C. S. Nunomura

UFAM: Universidade Federal do Amazonas

Research Article

Keywords: Amazon, plant, biological control, Aedes, Anopheles

Posted Date: January 6th, 2022

DOI: https://doi.org/10.21203/rs.3.rs-1157100/v1

License: (c) (i) This work is licensed under a Creative Commons Attribution 4.0 International License.

Read Full License

Version of Record: A version of this preprint was published at Environmental Science and Pollution Research on February 18th, 2022. See the published version at https://doi.org/10.1007/s11356-022- 
19196-w.

Page $2 / 29$ 


\section{Abstract}

The mosquitoes vectors of the genus Aedes and Anopheles present resistance to several commercial insecticides, which are also toxic to non-predators targets. On the other hand, essential oils are a promising source of insecticides. Thus, in this work, the essential oil from the leaves of Piper purusanum was characterized by gas chromatography based approaches and evaluated as biodefensive against malaria and dengue vectors. The main compounds of $P$. purusanum essential oil were $\beta$-caryophyllene (57.05\%), $a$-humulene (14.50\%) and germacrene $\mathrm{D}(8.20 \%)$. The essential oil inhibited egg hatching $(7.6 \pm$ 1.5 to $95.6 \pm 4.5 \%)$ caused larval death $\left(\mathrm{LC}_{50}\right.$ from 49.84 to $\left.51.60 \mathrm{ppm}\right)$ and inhibited the action of acetylcholinesterase $\left(\mathrm{IC}_{50}\right.$ of $\left.2.29 \mu \mathrm{g} / \mathrm{mL}\right)$, which can be related to the mechanisms of action. On the other hand, the biological activity of $\beta$-caryophyllene, $\alpha$-humulene and germacrene $\mathrm{D}$ were higher than the essential oil. In addition, these sesquiterpenes and essential oil did not show a lethal effect on Toxorhynchites splendens, Anisops bouvieri, Gambusia affinis and Diplonychus indicus ( $\mathrm{LC}_{50}$ from 2098.80 to $7707.13 \mathrm{ppm}$ ), although $D$. indicus is more sensible (SI/PSF from 48.56 to $252.02 \mathrm{ppm}$ ) to essential oil, representing a natural alternative against these relevant vectors.

\section{Introduction}

Malaria and dengue are fatal infections diseases caused by etiological agents of the Plasmodium (Plasmodidae) and Flavivirus (Flaviviridae) genera, which in 2019 caused respectively 229 and 390 million infections in all the world (PAHO 2020a; WHO 2021), while in South of America, $65 \%$ of these infections occurred in Brazil (WHO 2020; PAHO 2020b). In Brazil, malaria is mainly transmitted by the mosquito of the species Anopheles darlingi, while An. nuneztovari, An. triannulatus and An. albitarsis are secondary transmitters (Consoli and Lourenço 1994). These mosquitoes are endemic to the rural area of the State of Amazonas, which concentrates $99 \%$ of cases of the disease, with 157.454 infections and 37 deaths reported only 2019 (Ministry of Health 2021a, b). On the other hand, dengue is endemic to urban areas due to the characteristics of the main vector, Aedes aegypti, while Ae. albopictus is classified as a secondary vector (WHO 2021). In 2019, Brazil notified to the World Health Organization, 1.544.987 infections and 1.077 deaths were caused by dengue (Ministry of Health 2019). Difficulties in controlling dengue and malaria occur because the vectors are resistant to commercial insecticides, which are also toxic to non-target predators (Braga and Valle 2007; Melo-Santos et al. 2010; Nogueira et al. 2010; Aguirre-Obando et al. 2016). This resistance was identified as one determining factor for the dissemination of malaria and dengue epidemics that occurred in Brazil between 2010 and 2016 (Ministry of Health 2021a, b). Actually, plant-based products, especially essential oils, are promising natural insecticides (Qin et al. 2010; Marques et al. 2017; Janarium et al. 2018), for example, essential oils from Zanthoxylum limonella Alston (Rutaceae) against Ae. aegypti (Soonwera et al. 2017) and Kaempferia galanga L. (Zingiberaceae) evaluated against Ae. vittatus and An. maculatus (Culicidae) (AlSalhi et al. 2020). The Piper genus is the largest in the Piperaceae family, with approximately 2.000 plant species (Marques and Kaplan 2015), to which essential oils have shown promising biological activities against mosquitoes of the Aedes and Anopheles genera (Matasyoh et al. 2011; Villamizar et al. 2017; Kanis et al. 
2018). P. purusanum C.DC have a restricted distribution in the State of Amazonas, Brazil (Guimarães et al. 2020), with no chemical and biological knowledge reported so far. Thus, in the present work, the essential oil from the leaves of P. purusanum was characterized by GC-MS and GC-FID, and evaluated as biodefensive against malaria and dengue vectors based on inhibition egg hatching, larvicidal and anticholinesterase activities, and toxicity against non-target predators. In addition, the main compounds from essential oil were also evaluated as potential biodenfensive agents.

\section{Materials And Methods}

\section{Instruments and chemicals}

A knife mill (SL-31, Solab, Brazil), a heating mantle (52E, Fisatom, Brazil) and a chiller (Julabo GMBH, Biovera, Brazil) were used in the essential oil distillation procedure. A pH meter (PHS3BW, Bel Engineering,

Brazil) and a refractometer (Master-T, Atago, Brazil) were used to measure the physical chemistry properties of the essential oil. A GC-MS system constituted by a Trace GC Ultra gas chromatograph coupled to an ISQ mass spectrometer (Thermo Scientific, USA) and a GC-FID system (G-1860 Plus, Agilent equipment, USA) were used for the chemical analysis of the essential oil. A microplate reader (ELx800, Biotek, USA) was used in the acetylcholinesterase (AChE) assay. A microscope (Stemi 200-C, Zeizz, Germany) was used in the egg hatch inhibition test.

The AChE from Electrophorus electricus (200-1.000 units/mg protein), 5,5'-dithiobis-2-nitrobenzoic acid (DTNB) (98\%), acetylcholine iodide (AChl) (97\%), tris(hydroxymethyl)aminomethane (99.8\%), $\beta$ caryophyllene (80\%), $\alpha$-humulene (90\%), $\mathrm{MeOH}(99.8 \%)$, temephos (Pestanal $\left.{ }^{\circledR} 95 \%\right)$, anhydrous sodium sulfate $\left(\mathrm{Na}_{2} \mathrm{SO}_{4}\right)(99 \%), n$-alkanes series (C8-C30) (Supelco) and dimethylsulfoxide (DMSO) $(99.7 \%)$ were purchased from Merck, Brazil. The germacreno D (99\%) was purchased from Jinlan Pharm-Drugs Techlonogy, Hangzhou, China.

\section{Plant collection and distillation of essential oil}

The leaves of $P$. purusanum were collected in September, 2015, in Manaus, Amazonas, Brazil (Latitude $2^{\circ} 46^{\prime} 58.2^{\prime \prime} \mathrm{S}$, Longitude $60^{\circ} 05^{\prime} 2.8^{\prime \prime} \mathrm{W}$ ). The voucher (HUAM No. 11425) was deposited in the herbarium at Federal University of Amazonas. For the essential oil extraction, $50 \mathrm{~g}$ of the powdered leaves of $P$. purusanum were subjected to hydrodistillation using a Clevenger-type apparatus for $1 \mathrm{~h}$. The essential oil was dried using anhydrous sodium sulfate $\left(\mathrm{Na}_{2} \mathrm{SO}_{4}\right)$ and stored in an ambar glass vial at - $4{ }^{\circ} \mathrm{C}$ until analysis (de Oliveira et al. 2020). The values of pH, refractive index (Anjali et al. 2012), density and yield also were determined (Girard et al. 2007). All of the procedures were conducted in triplicate.

\section{GC-MS and GC-FID analyses of essential oil}

The GC-MS and GC-FID analyses of essential oil from P. purusanum were performed according to with previously reported methodology (de Oliveira et al. 2020). The retention index (RI) was obtained using the $n$-alkanes series (C8-C30) and the Van Den Dool and Kratz equation (Van Den Dool and Kratz, 1963). The 
identification of each compound was done by comparison of the obtained retention index with the ones found in the literature (Adams 2017; NIST 2020).

\section{Mosquitoes rearing}

The Ae. aegypti and Ae. albopictus mosquitoes were reared at the Laboratório de Malária e Dengue at INPA under controlled temperature $\left(26 \pm 3^{\circ} \mathrm{C}\right)$, relative humidity $(85 \%)$ and photoperiod $(24 \mathrm{~h})$ (Silva et al., 2014). Mosquitoes of the species An. triannulatus, An. darlingi, An. nuneztovari and An. albitarsis were collected following the WHO methodology (WHO 1975) at the Ramal Brasileirinho (Latitude $3^{\circ} 0^{\prime} 42.9^{\prime \prime} \mathrm{S}$, Longitude 59 $52^{\prime} 29.9^{\prime \prime W}$ ), Manaus, Amazonas, Brazil. These mosquitoes were identified using taxonomic keys (Gorham et al. 1973; Faran and Linthicum 1981; Consoli and Lourenço 1994) and reared in the same conditions. The blood meal of female mosquitoes was performed in Mesocricetus auratus (Cricetidae) hamsters.

\section{Egg hatch inhibition assay}

Egg hatch inhibition was evaluated following the method described by Rajkumar et al. (2011) with some modifications. Briefly, the eggs $(n=100)$ were divided into five groups (20 eggs each), distributed in plastic cups $(200 \mathrm{~mL})$ and treated for $3 \mathrm{~h}$ with concentrations from 1.95 to $31.25 \mathrm{ppm}$ of the essential oil, $\beta$-caryophyllene, germacrene $D$ and $\alpha$-humulene prepared in $1 \mathrm{~mL}$ of DMSO. Each concentration contained five replicates. Subsequently, the eggs were transferred to plastic cups containing $100 \mathrm{~mL}$ of distilled water. DMSO and temephos also were evaluated at these concentrations. Eggs were observed under a microscope after $120 \mathrm{~h}$ to evaluate the percentage of inhibition at each concentration using the formula: number of unhatched eggs / Total number of eggs exposed $x 100$.

\section{Larvicidal assay}

The larvicidal activity was carried out following the WHO (2005) protocol. The $3^{\text {rd }}$ instar larvae $(n=100)$ were distributed in plastic cups $(500 \mathrm{~mL})$ containing $249 \mathrm{~mL}$ of distilled water and essential oil concentrations ( 25 to $125 \mathrm{ppm}$ ), $\beta$-caryophyllene, germacrene $D$ and $\alpha$-humulene (10 to $50 \mathrm{ppm}$ ) prepared in $1 \mathrm{~mL}$ of DMSO. Concentrations were followed by five replicates. DMSO was evaluated at concentrations from 25 to 125 ppm, while temephos was evaluated at concentrations from 0.78 to 12.5 $\mathrm{ppm}$. The percentage of activity at each concentration was calculated after $24 \mathrm{~h}$ using the equation (1).

$$
\text { Larvicida activity } \%=\frac{\text { number of dead larvae }}{\text { number of larvae used }} \times 100
$$

\section{Toxicity assessment in non-target predators}

The toxicity of essential oil, $\beta$-caryophyllene, germacrene $D$ and $\alpha$-humulene was evaluated following the methodology described by Sivagnaname and Kalyanasundaram (2004), with some modifications. Briefly, the species A. bouvieri (Hemiptera), D. indicus (Heteroptera), T. splendens (Culicidae) and G. affinis (Poeciliidae) were collected at INPA and identified using a taxonomic key (Hamada et al. 2014). Besides, 
these samples were acclimated in a tank glass $(90 \mathrm{~cm}$ in diameter and $40 \mathrm{~cm}$ deep) containing $5 \mathrm{~L}$ of potable water for $24 \mathrm{~h}$ and distributed in plastic cups containing $499 \mathrm{~mL}$ of potable water and concentrations of 250 to $2000 \mathrm{ppm}$ prepared in $1 \mathrm{~mL}$ of DMSO. The negative control was evaluated at these concentrations, while temephos was evaluated at concentrations from 0.78 to $12.5 \mathrm{ppm}$. Mortality and slow movements were monitored for 20 days. The Suitability index (SI) or Predator safety factor (PSF) was calculated for each species of predator using the equation (2) (Deo et al. 1988).

$$
S I / P S F=\frac{L C_{50} \text { of non }- \text { target organism }}{L C_{50} \text { of target vector specie }}
$$

\section{Acetylcholinesterase inhibition assay (AChE)}

Inhibition of AChE was performed by the colorimetric methodology described by Ellman et al. (1961) with modifications. Briefly, neostigmine $(1 \mathrm{mg})$ and AChE $(10 \mu \mathrm{L})$ were prepared in phosphate buffer $(1 \mathrm{~mL})$ of a $0.1 \mathrm{M}$ solution at $\mathrm{pH} 8$, while $\beta$-caryophyllene, germacrene $\mathrm{D}$, $\alpha$-humulene and essential oil $(1 \mathrm{mg})$ were prepared in $\mathrm{MeOH}(1 \mathrm{~mL})$ and evaluated at concentrations from 0.07 to $10 \mathrm{ppm}$. The test was performed in triplicate using a 96-well microplate incubated in an environment protected from light for 15 minutes. Negative and positive controls were evaluated under these conditions. Absorbance readings were taken ten times at a wavelength of $405 \mathrm{~nm}$ for $30 \mathrm{~min}$ with an interval of $5 \mathrm{~min}$. The percentage of inhibition at each concentration was calculated according to the equation (3).

$$
\text { Inhibition } \%=A^{2}-\left(A^{1}-A^{3}\right) x \frac{100}{A^{2}}
$$

where: $A^{1}$ is the absorption of the samples and the enzyme, $A^{2}$ is the absorption of the enzyme without the sample, and $A^{3}$ is the sample absorption without the enzyme.

\section{Statistical analysis}

Probit analysis (Finney 1971) was used to identify the $\mathrm{LC}_{50}$ and $\mathrm{LC}_{90}$ using the PoloPlus program (Leora Software Berkeley, CA, USA). In the AChE assay, absorbances were normalized and analyzed using the non-linear regression method to identify the $\mathrm{IC}_{50}$. All data were analyzed using ANOVA followed by Tukey test $(p<0.05)$ through the GraphPad Prism statistical program version 7 (de Oliveira et al. 2020).

\section{Results And Discussion}

\section{Essential oil analysis}

The essential oil was extracted from $P$. purusanum leaves with a yield of $4.2 \pm 0.7 \%$, pH of $5.3 \pm 1.9$, density of $0.974 \mathrm{~g} / \mathrm{cm}^{3}$ and refractive index of 1.941 . The GC-MS and GC-FID analysis pointed sesquiterpenes oxygenated and sesquiterpenes hydrocarbons, especially $\beta$-caryophyllene $(57.50 \%), \alpha$ humulene (14.50\%), germacrene D (8.20\%) (Fig. 1), E-nerolidol (4.20\%) and caryophyllene oxide (3.46\%) 
as the main compounds in the essential oil (Table 1). This chemical profile is similar to that observed in the essential oils of the species $P$. amalago L., $P$. umbellatum L., $P$. dilatatum LC, Rich, P. leptorum Kunth, $P$. amplum Kunth, $P$. gaudichaudianum Kunth and $P$. crassinervium Kunth, which demonstrated significant anti-cancer, anti-inflammatory, antibacterial, repellent, anti-fungal, anti-malarial, anti-leishmanial, and larvicidal activities (Guerrini et al. 2009; Andrade et al. 2011; Kelly et al. 2014; Vaz et al. 2016; Ventorim et al. 2016; Ravi et al. 2006; Raphael et al. 2013; Sperotto et al. 2013; Nararak et al. 2020).

\section{Egg hatch assay}

The leaves essential oil of $P$. purusanum from 15.62 to $31.25 \mathrm{ppm}$ showed higher activity in inhibiting the hatching of eggs (Table 2) of Ae. aegypti, Ae. albopictus, An. albitarsis, An. triannulatus, An. darlingi and An. nuneztovari ( $63.3 \pm 5.1$ to $98.0 \pm 3.4 \%)$ than temephos $(7.0 \pm 2.1$ to $57.0 \pm 1.1 \%)(p<0.05)$, as well as to $\beta$-caryophyllene $(0.6 \pm 0.5$ to $54.6 \pm 7.2 \%)$, $a$-humulene $(1.0 \pm 1.0$ to $61.3 \pm 5.8 \%)$ and germacrene $D$ $(1.3 \pm 1.5$ to $54.6 \pm 2.5 \%)(p<0.05)$ sesquiterpenes. Similar results to the essential oil of $P$. purusanum were observed in the species Limonia acidissima L. (Rutaceae), Sophora alopecuroides (Fabaceae) and Coleus aromaticus (Lamiaceae), whose main compounds were niloticin, sophocarpin, and $\beta$ caryophyllene, respectively (Reegan et al. 2014; Baranitharan et al. 2017; Shoukat et al. 2020).

The inhibition of hatching of eggs caused by essential oils and commercial insecticides occurs by inhibiting the synthesis of ecdysone, juvenile hormone, and chitin, which causes the death of the embryon due to malformation (Suman et al. 2013). Furthermore, these promising agents also obstruct the chorion, preventing the exchange between $\mathrm{CO}_{2}$ and $\mathrm{O}_{2}$ gases resulting in the accumulation of $\mathrm{CO}_{2}$ within the eggs causing embryo death from anoxia (de Oliveira et al. 2020; Kala et al. 2019; Mehlhorn et al. 2011).

\section{Larvicidal assay}

The essential oil of $P$. purusanum showed high activity against An. nuneztovari, An. triannulatus, An. darlingi and An. albitarsis larvae ( $\mathrm{LC}_{50}$ from 49.84 to $51.61 \mathrm{ppm}$ ) (Table 3), as well as against Ae. aegypti and Ae. albopictus larvae ( $\mathrm{LC}_{50}$ from 42.62 to $53.41 \mathrm{ppm}$ ) (Table 4). On the other hand, the $\beta$ caryophyllene, $a$-humulene and germacrene $\mathrm{D}$ showed higher activity against Anopheles $\left(\mathrm{LC}_{50}\right.$ from 24.49 to $33.08 \mathrm{ppm}$ ) and Aedes larvae ( $\mathrm{LC}_{50}$ from 28.11 to $\left.35.96 \mathrm{ppm}\right)$ than essential oil $(p<0.05)$. However, the activity of essential oil and sesquiterpenes were lower $(p<0.05)$ than temephos $\left(\mathrm{LC}_{50}\right.$ from 3.85 to $5.45 \mathrm{ppm})$ and Aedes larvae ( $\mathrm{LC}_{50}$ from 3.21 to $\left.2.75 \mathrm{ppm}\right)$.

The larvicidal activity of the essential oil of $P$. purusanum is in agreement with previously published data to species $P$. capense LF ( $\left(\mathrm{CC}_{50}\right.$ from 34.9 to $85.10 \mathrm{ppm}$ ), P. corcovadensis (Miq.) (LC ${ }_{50}$ from $30.52 \mathrm{ppm}$ ) and $P$. alatipetiolatum Yunck ( $\mathrm{LC}_{50}$ of $33.74 \mathrm{ppm}$ ) (Piperaceae), which presented significant activity against Aedes, Anopheles and Culex larvae (Govindarajan et al. 2011; Matasyoh et al. 2011; da Silva et al. 2016; de Oliveira et al. 2020). Furthermore, the larvicidal activity of $\beta$-caryophyllene, $\alpha$-humulene and germacrene D corroborates other larvicidal studies (Ravi et al. 2006; Govindarajan and Benelli 2016a, b). Although caryophyllene oxide, $\alpha$-terpineol, $\beta$-selinene and $E$-nerolidol were not investigated in our study, 
they are important larvicidal agents (Cheng et al. 2004; Pavela 2015; Huang et al. 2019), and could contribute through a synergic effect to the improvement of the larvicidal activity.

During the experiments, the larvae showed tremors, slow movements, extrusion of the peritrophic membrane and darkening of the whole body. These changes also observed in other essential oil studies are triggered by the collapse of the central nervous system after inhibition of the enzyme acetylcholinesterase, as well as inhibition of the digestive and hormonal system (Abed et al. 2007; Barreto et al. 2007; Al-Mehmadi and Al-Khalaf 2010).

\section{Toxicity to non-target predators}

The results of toxicity against non-targed predators $A$. bouvieri, T. splendens, G. affinis and $D$. indicus were presented in table 5 and showed that the $\mathrm{LC}_{50}$ values of the essential oil from $P$. purusanum $\left(\mathrm{LC}_{50}\right.$ from 2506.56 to 7707.13 ppm), $\beta$-caryophyllene ( LC $_{50}$ from 4418.14 to $6335.83 \mathrm{ppm}$ ), $\alpha$-humulene ( $\mathrm{LC}_{50}$ from 2386.94 to $6082.02 \mathrm{ppm}$ ) and germacrene D ( $\mathrm{LC}_{50}$ from 2098.80 to $5429.94 \mathrm{ppm}$ ) were lower than temephos ( $\mathrm{LC}_{50}$ of 4.85 to $5.81 \mathrm{ppm}$ ). In addition, the SI/PSF values against Anopheles was from 48.57 to 252.02 (Table 6) and SI/PSF values against Aedes was from 46.93 to 216.36 (Table 7), suggesting that the $\mathrm{LC}_{50}$ values of the essential oil, $\beta$-caryophyllene, $\alpha$-humulene and germacrene $\mathrm{D}$ are not toxic to these predators (Table 3 and 4). Moreover, the swimming activity of predators was not affected by essential oil and sesquiterpenes during the 20 days.

The species A. bouvieri, T. splendens, G. Affinis, D. Indicus and Poecilia reticulata (Poeciliidae) are important bioindicators of the toxicity of natural plant products (Govindarajan 2016; Benelli et al. 2018). For example, the extract of Monofilla atlantia (Roxb.) A.DC (Rutaceae) $\left(\mathrm{LC}_{50}\right.$ from 0.14 to $23.36 \mathrm{mg} / \mathrm{mL}$ ) (Sivagnaname and Kalyanasundaram 2004) and the compound thymol ( $\mathrm{LC}_{50}$ from 12.51 to 10.99 $\mathrm{mg} / \mathrm{mL}$ ) were more toxic against $P$. reticulata than 1,8-cineole $\left(\mathrm{LC}_{50}\right.$ from 3997.07 to $1701.93 \mathrm{mg} / \mathrm{mL}$ ) (Bullangpoti et al. 2018).

\section{Acetylcholinesterase inhibition assay (AChE)}

The AChE inhibitory activity of $P$. purusanum essential oil ( $\mathrm{IC}_{50}$ of $\left.2.29 \mathrm{ppm}\right)$ was higher than $\beta$ caryophyllene ( $\mathrm{IC}_{50}$ of $\left.5.37 \mathrm{ppm}\right)$, $a$-humulene $\left(\mathrm{IC}_{50}\right.$ of $\left.4.36 \mathrm{ppm}\right)$ and germacrene $\mathrm{D}\left(\mathrm{IC}_{50}\right.$ of $\left.10.91 \mathrm{ppm}\right)$ (Table 8). Besides, the AChE inhibitory activity was $\mathrm{IC}_{50}$ of $0.77 \mathrm{ppm}$ for neostigmine. The enzymatic action of the essential oil of $P$. purusanum corroborates with species $P$. hispidum $\mathrm{Sw}_{\text {., }}\left(\mathrm{IC}_{50}\right.$ of $\left.0.01 \mathrm{ppm}\right)$, P. anonifolium Kunth, ( $\left(\mathrm{IC}_{50}\right.$ of $\left.0.01 \mathrm{ppm}\right)$, P. aleyreanum C.DC ( $\left(\mathrm{I}_{50}\right.$ of $10 \mathrm{ppm}$ ) (Kelly et al. 2014) and $P$. betle L. ( $\mathrm{IC}_{50}$ of 0.11 to $0.47 \mathrm{ppm}$ ) (Karak et al. 2018).

The literature demonstrates that several compounds obtained from plants and essential oils present high AChE inhibitory activity, for example, Acorus calamus L. (Acoraceae) ( $\mathrm{IC}_{50}$ of $\left.9.48 \mathrm{ppm}\right)$, Cyperus rotundus L. (Cyperaceae) ( $\left(\mathrm{IC}_{50}\right.$ of $\left.22.05 \mathrm{ppm}\right)$, Azadirachta indica A. Juss. (Meliaceae) $\left(\mathrm{IC}_{50}\right.$ of $\left.5.8 \mathrm{ppm}\right)$ 
(Vinutha et al., 2007), 1,8-cineole ( $\mathrm{IC}_{50}$ of $\left.670 \mu \mathrm{M}\right)$, (+)-a-pinene $\left(\mathrm{IC}_{50}\right.$ of $\left.630 \mu \mathrm{M}\right)$ and (+)-pulegone $\left(\mathrm{IC}_{50}\right.$ of $890 \mu \mathrm{M})$ (Houghton et al. 2006).

Inhibition of AChE results in exhaustive stimulation of neurons due to the accumulation of acetylcholine in the synaptic slit, causing the collapse of the central nervous system, and resulting in exhaustive muscle contraction, involuntary muscle contractions, tremors, later lethargic movements that follow the death of the mosquitoes (Vinutha et al. 2007; Al-Mehmadi and Al-Khalaf 2010). These reactions were also observed with Anopheles and Aedes larvae, as well as extrusion of the peritrophic membrane and darkening of the larvae during exposure to $P$. purusanum essential oil, $\beta$-caryophyllene, $\alpha$-humulene and germacrene D. Due to the complexity of the chemical composition of essential oils, the mechanisms of action are attributed to the various compounds and their ability to penetrate the insects body, acting on specific enzymes of the central nervous system (AlSalhi et al. 2020), digestive and hormonal (Lee et al. 2002; Barreto et al. 2007). The extrusion of the peritrophic membrane is classified as a defense mechanism for larvae to expel toxic compounds from the intestine (Abed et al. 2007). Darkening is caused by inhibition of the endocrine system, causing overlapping cuticles (Demirci et al. 2017). Thus, AChE inhibition can not be interpreted as the only mode of action (Kelly et al. 2014; AlSalhi et al. 2020).

\section{Conclusion}

In the present study, the first description of the chemical profile of the essential oil of $P$. purusanum and its insecticidal activity against vectors mosquitoes of malaria and dengue and non-target predators was reported. The obtained results demonstrate that $P$. purusanum essential oil and its main compounds are promising natural insecticide agents against malaria and dengue vectors without toxicity against nontarget predators. The investigation of the effects of essential oils and their main compounds on predators allows us to understand several parameters such as toxicity and selectivity. Thus, these results demonstrate that the essential oil of $P$. purusanum, as well as $\beta$-caryophyllene, $a$-humulene and germacrene $\mathrm{D}$ can be considered an effective alternative in the control of malaria and dengue.

\section{Declarations}

\section{Acknowledgments}

In memoriam to doctor Wanderli Pedro Tadei. We also thank the Graduate Program in Pharmaceutical Innovation, the Sample Opening and Chemical Testing Laboratory, Malaria and Dengue Laboratory, Amazon Active Principles Laboratory, Dr Rosemary Costa Pinto Health Surveillance Foundation, Analytical Center, Multidisciplinary Support Center, National Council for Scientific and Technological Development, Science and Technology, Amazonas State Research Support Foundation and Graduate Program in Pharmaceutical Innovation for all the support.

\section{Ethical Approval}


The collection of plant and mosquitoes were autorized by Sistema de Autorização e Informação em Biodiversidade (SISBIO) (No. 78388-1, No. 74151). The blood meal of female mosquitoes performed in hamsters was authorized by the Ethics Committee on the Use of Animals (No. 058/2018, SEI 01280.001882/2018-21). The study was registered in the Sistema Nacional de Gestão do Patrimônio Genético e do Conhecimento Tradicional Associado (SisGen) (No. ADC693C).

\section{Authors Contributions}

André C. de Oliveira, Felipe M. A. da Silva, Sergio M. Nunomura, Rosemary A. Roque, Wanderli P. Tadei and Rita C. S. Nunomura: Conceptualization, Methodology, Investigation, Formal analysis, Data Curation, Writing - Original Draft, Writing - Review \& Editing and Supervision. Carlos A. P. Lima and Rejane C. Simões: Conceptualization.

\section{Funding}

This project was supported by the National Council for Scientific and Technological Development, Science and Technology - Amazonia (077/2013, process no. 408172/2013-4); Ministry of Science, Technology and Innovation/National Council of Sciences and Technological Development (28/2018, process no. 432533/2018-4); Ministry of Science, Technology and Innovation/Science and Technology Agribusiness - Amazonia (process no. 403496/2013-6), as well as the Amazonas State Research Foundation (018/2015, No. 062.00549/2019).

\section{Competing Interests}

The authors declare that they have no competing interests.

Consent to Participate Not applicable

Consent to Publish Not applicable

Availability of data and materials Not applicable

\section{References}

Abed, R.A., Cavasin, G.M., Silva, H.H.G., Geris, R., Silva, I.G., 2007. Morphohistological alterations in larvae of Aedes aegypti (Linnaeus, 1762) (Diptera: Culicidae) caused by larvicidal oil-resin activity of the medicinal plant Copaifera reticulata Ducke (Leguminosae). Rev. Patol. Trop. 36, 75-86. https://doi.org/10.5216/rpt.v36i1.1819

Adams, R.P., 2017. Identification of essential oil components by gas chromatography/mass spectrometry, 4th Edt. Allured Publishing Corporation, Carol Stream. 809p.

Aguirre-Obando, O.A., Pietrobon, A.J., Bona, A.C.D., Navarro-Silva, M.A., 2016. Contrasting patterns of insecticide resistance and knockdown resistance $(k d r)$ in Aedes aegypti populations from Jacarezinho 
(Brazil) after a dengue outbreak. Rev. Bras. Entomol. 60, 94-100.

https://doi.org/10.1016/j.rbe.2015.11.009

Al-Mehmadi, R.M., Al-Khalaf, A.A., 2010. Larvicidal and histological effects of Melia azedarach extract on Culex quinquefasciatus Say larvae (Diptera: Culicidae). J. King Saud. Univ. Sci. 22, 77-85. https://doi.org/10.1016/j.jksus.2010.02.004

AlSalhi, M., Elumalai, K., Devanesan, S., Govindarajan, M., Krishnappa, K., Maggi, F., 2020. The aromatic ginger Kaempferia galanga L. (Zingiberaceae) essential oil and its main compounds are effective larvicidal agents against Aedes vittatus and Anopheles maculatus without toxicity on the non-target aquatic fauna. Ind. Crops. Prod. 158: 11312. https://doi.org/10.1016/j.indcrop.2020.113012

Andrade, E.H.A., Alves, C.N., Guimarães, E.F., Carreira, L.M.M., Maia, J.G.S., 2011. Variability in essential oil composition of Piper dilatatum L.C Rich. Biochem. System. Ecol. 39, 669-

675. https://doi.org/10.1016/j.bse.2011.05.021

Anjali, C.H., Sharma, Y., Mukherjee, A., Chandrasekaran, N., 2012. Neem oil (Azadirachta indica) nanoemulsion - a potent larvicidal agent against Culex quinquefasciatus. Pest Manag Sci 68:158-163. https://doi.org/10.1002/ps.2233

Baranitharan, M., Dhanasekaran, S., Kovendan, K., Murugan, K., Gokulakrishnan, J., Benelli, G., 2017. Coleus aromaticus leaf extract fractions: A source of novel ovicides, larvicides and repellents against Anopheles, Aedes and Culex mosquito vectors? Process. Saf. Environ. Prot. 106: 23-33. http://dx.doi.org/10.1016/j.psep.2016.12.003

Barreto, C.F., Cavasin, G.M., Garcia da Silva, H.H., Da Silva, I.G., 2007. Study of morphohistological alterations in larvae of Aedes aegypti (Diptera: Culicidae) submitted to the crude ethanol extract Desapindus saponaria lin (Sapindaceae). Rev. Patol. Trop. 35, 37-57.

https://doi.org/10.5216/rpt.v35i1.1891

Benelli, G., Rajeswary, M., Govindarajan, M., 2016. Towards green oviposition deterrents? Effectiveness of Syzygium lanceolatum (Myrtaceae) essential oil against six mosquito vectors and impact on four aquatic biological control agents. Environ. Sci. Pollut. Res. (2018) 25:10218-10227

Braga, I.A., Valle, D., 2007. Aedes aegypti: insecticides, mechanisms of action and resistance. Epidemiol. Serv. Saud. 16, 279-293. https://doi.org/10.5123/S1679-49742007000400006

Brazilian Ministry of Health, 2021b. Epidemiological Bulletin. boletim_especial_malaria_1dez20_final.pdf (www.gov.br) (Accessed August 12, 2021).

Bullangpoti, V., Mujchariyakul, W., Laksanavilat, N., 2018. Acute toxicity of essential oil compounds (thymol and 1,8-cineole) to insectivorous guppy, Poecilia reticulata Peters, 1859. Agric. Nat. Resour. 5: 190-194. https://doi.org/10.1016/j.anres.2018.06.011 
Cheng, S.S., Liu, J.Y., Tsai, K.H., Chen, W.J., Chang, S.T., 2004. Chemical composition and mosquito larvicidal activity of essential oils from leaves of different Cinnamomum osmophloeum provenances. J. Agric. Food Chem. 52, 4395-4400. https://doi.org/10.1021/jf0497152

Consoli, R.A.G.B. and Oliveira, R.L. De., 1994. Main mosquitoes of sanitary importance in Brazil. Primeira ed. Fiocruz, Rio de Janeiro.

da Silva, M.F.R., Bezerra-Silva, P.C., de Lira, C.S., de Lima Albuquerque, B.N., Agra Neto, A.C., Pontual, E.V., Maciel, J.R., Paiva, P.M.G., Navarro, D.M. do A.F., 2016. Composition and biological activities of the essential oil of Piper corcovadensis (Miq). C.DC (Piperaceae). Exp. Parasitol. 165. 64-

70. 10.1016/j.exppara.2016.03.017

de Oliveira, A.C., Sá, I.S.C., Mesquita, R.S., Pereira, B.L., Pocrifka, L.A., de Souza, T.P., Rodriguez Amado, J.R., Azevedo, S.G., Sanches, E.A., Nunomura, S.M., Roque, R.A., Tadei, W.P., Nunomura, R.C.S., 2020. Nanoemulsion loaded with volatile oil from Piper alatipetiolatum as an alternative agent in the control of Aedes aegypti. Rev. Bras. Farmacogn. 30, 667-677. https://doi.org/10.1007/s43450-020-00092-8

Demirci, B., Yusufoglu, H.S., Tabanca, N., Temel, H.E., Bernier, U.R., Agramonte, N.M., Alqasoumi, S.I., AlRehaily, A.J., Başer, K.H.C., Demirci, F., 2017. Rhanterium epapposum Oliv. essential oil: Chemical composition and antimicrobial, insect-repellent and anticholinesterase activities. Saudi Pharm. J. 25, 703-708. https://doi.org/10.1016/j.jsps.2016.10.009

Deo, P.G., Hasan, S.B., Majumdar, S.K., 1988. Toxicity and suitability of some insecticides for household use. Int. Pest Control. 30, 118-129

Ellman, G.L., Courtney, K.D., Andres, V., Featherstone, R.M., 1961. A new and rapid colourimetric determination of acetylcholinesterase activity. Biochemi. Pharmacol. 7, 8895. https://doi.org/10.1016/0006-2952(61)90145-9

Faran, M.E. Linthicum, K.J., 1981. A handbook of the Amazon species of Anopheles Nyssorhynchus) (Diptera: Culicidae). Mosquito System. 13, 1-81

Finney, D.J., 1971. Probit Analysis. Cambridge University Press, London, pp. 68-72

Forgiarini, A., Esquena, J., González, C., Solans, C., 2001. Formation of nano-emulsions by low-energy emulsification methods at constant temperature. Langmuir 17, 20762083. https://doi.org/10.1021/la001362n

Girard, E.A., Koehler, H.S., Netto, S.P., 2007. “Craveiro” (Pimenta Pseudocaryophyllus (Gomes) Landrum). Essential oil, volume, biomass and yield. Rev Acad 5:147-165.

Govindarajan, M., 2011. Larvicidal and repellent properties of some essential oils against Culex tritaeniorhynchus Giles and Anopheles subpictus Grassi (Diptera: Culicidae). Asian Pac. J. Trop Med. 4, 106-111. https://doi.org/10.1016/S1995-7645(11)60047-3 
Govindarajan, M., Benelli, G., 2016a. Eco-friendly larvicides from Indian plants: Effectiveness of lavandulyl acetate and bicyclogermacrene on malaria, dengue and Japanese encephalitis mosquito vectors. Ecotoxicol. Environ. Saf. 133, 395-402. https://doi.org/10.1016/j.ecoenv.2016.07.035

Govindarajan, M., Benelli, G., 2016b. $\alpha$-Humulene and $\beta$-elemene from Syzygium zeylanicum (Myrtaceae) essential oil: highly effective and eco-friendly larvicides against Anopheles subpictus, Aedes albopictus, and Culex tritaeniorhynchus (Diptera: Culicidae). Parasitol. Res. 115, 2771-2778.

https://doi.org/10.1007/s00436-016-5025-2

Govindarajan, M., Mathivanan, T., Elumalai, K., Krishnappa, K., Anandan, A., 2011. Ovicidal and repellent activities of botanical extracts against Culex quinquefasciatus, Aedes aegypti and Anopheles stephensi (Diptera: Culicidae). Asian Pac. J. Trop. Biomed. 1, 43-48. https://doi.org/10.1016/S22211691(11)60066-X

Guerrini, A., Sacchetti, G., Rossi, D., Paganetto, G., Muzzoli, M., Andreotti, E., Tognolini, M., Maldonado, M.E., Bruni, R., 2009. Bioactivities of Piper aduncum L. and Piper obliquum Ruiz \& Pavon (Piperaceae) essential oils from Eastern Ecuador. Environ. Toxicol. Pharmacol. 27, 39-48.

https://doi.org/10.1016/j.etap.2008.08.002

Guimarães, E.F.; Queiroz, G.A.; Medeiros, E.V.S.S., 2020. Piper in Flora do Brazil. Botanical Garden of Rio de Janeiro. Available at: http://floradobrasil.jbri.gov.br/reflora/floradobrasil/FB86652 (Accessed 9 January 2021).

Hamada, N., Nessimian, J.L., Querino, R.B., 2014. Aquatic insects in the Brazilian Amazon: taxonomy, biology and ecology. Publisher INPA. 724p.

Houghton, P., Ren, Y., Howes, M.J., 2006. Acetylcholinesterase inhibitors from plants and fungi. Nat. Prod. Rep. 23: 181-199. https://doi.org/10.1039/b508966m

Huang, Y., Lin, M., Jia, M., Hu, J., Zhu, L., 2019. Chemical composition and larvicidal activity against Aedes mosquitoes of essential oils from Arisaema fargesii. Pest Manag. Sci. 76: 534-542. https://doi.org/10.1002/ps.554

Janaki, S., Zandi-Sohani, N., Ramezani, L., Szumny, A., 2018. Chemical composition and insecticidal efficacy of Cyperus rotundus essential oil against three stored product pests. Int. Biodeter. Biodegradation. 133, 93-98. https://doi.org/10.1016/j.ibiod.2018.06.008

Kala, S., Naik, S.N., Patanjali, P.K., Sogan, N., 2019. Neem oil water-dispersible tablet as effective larvicide, ovicide and oviposition deterrent against Anopheles culicifacies. South African J. Bot. 123, 387-392. https://doi.org/10.1016/j.sajb.2019.03.033

Kanis, L.A., Rabelo, B.D., Moterle, D., Custódio, K.M., de Oliveira, J.G., de Lemos, A.B., da Silva, O.S., Zepon, K.M., Magnago, R.F., Prophiro, J.S., 2018. Piper ovatum (Piperaceae) extract/starch-cellulose films to 
control Aedes aegypti (Diptera: Culicidae) larvae. Ind. Crops. Prod. 122, 148-155. https://doi.org/10.1016/j.indcrop.2018.05.055

Karak, S., Acharya, J., Begum, S., Mazumdar, I., Kundu, R., De, B., 2018. Essential oil of Piper bet/e L. leaves: Chemical composition, anti-acetylcholinesterase, anti- $\beta$-glucuronidase and cytotoxic properties. J. Appl. Res. Medic. Aromat. Plant. 10, 85-92. https://doi.org/10.1016/j.jarmap.2018.06.006

Kelly, J., Silva, R., Pinto, L.C., Burbano, R.M.R., Montenegro, R.C., Guimarães, E.F., Helena, E., Andrade, A., Guilherme, J., Maia, S., 2014. Essential oils of Amazon Piper species and their cytotoxic, antifungal, antioxidant and anti-cholinesterase activities. Ind. Crops. Prod. 58, 55-60. https://doi.org/10.1016/j.indcrop.2014.04.006

Lee, S., Peterson, C.J., Coats, J.R., 2002. Fumigation toxicity of monoterpenoids to several stored product insects. J. Stored Prod. Res. 39, 77-85. https://doi.org/10.1016/S0022-474X(02)00020-6

Marques, A.M., Kaplan, M.A.C., 2015. Active metabolites of the genus Piper against Aedes aegypti: Natural alternative sources for dengue vector control. Univ. Sci. 20, 61-82.

https://doi.org/10.11144/Javeriana.SC20-1.amgp

Marques, A.M., Velozo, L.S., Carvalho, M.A., Serdeiro, M.T., Honório, N.A., Kaplan, M.A.C., Maleck, M., 2017. Larvicidal activity of Ottonia anisum metabolites against Aedes aegypti: A potential natural alternative source for mosquito vector control in Brazil. J. Vector Borne Dis. 54, 61-68.

Matasyoh, J.C., Wathuta, E.M., Kariuki, S.T., Chepkorir, R., 2011. Chemical composition and larvicidal activity of Piper capense essential oil against the malaria vector, Anopheles gambiae. J. Asia Pac. Entomol. 14, 26-28. https://doi.org/10.1016/j.aspen.2010.11.005

Mehlhorn, H., Abdel-ghaffar, F., Semmler, M., 2011. Ovicidal effects of a neem seed extract preparation on eggs of body and head lice 1299-1302. https://doi.org/10.1007/s00436-011-2374-8

Melo-Santos, M.A.V., Varjal-Melo, J.J.M., Araújo, A.P., Gomes, T.C.S., Paiva, M.H.S., Regis, L.N., Furtado, A.F., Magalhaes, T., Macoris, M.L.G., Andrighetti, M.T.M., Ayres, C.F.J., 2010. Resistance to the organophosphate temephos: Mechanisms, evolution and reversion in an Aedes aegypti laboratory strain from Brazil. Acta Trop. 113, 180-189. https://doi.org/10.1016/j.actatropica.2009.10.015

Ministry of Health of Brazil, 2021a. Malária. Malária - Português (Brasil) (www.gov.br) (Accessed August $12,2021)$.

Nararak, J., Sathantriphop, S., Kongmee, M., Mahiou-Leddet, V., Ollivier, E., Manguin, S., Chareonviriyaphap, T., 2019. Excito-repellent activity of $\beta$-caryophyllene oxide against Aedes aegypti and Anopheles minimus. Acta Trop. 197, 105030. https://doi.org/10.1016/j.actatropica.2019.05.021 
National Institute of Standards and Technology (NIST), 2011. Standard reference database. NIST Chemistry WebBook. http://webbook. nist.gov/chemistry (Accessed November 24, 2020).

Nogueira, A.J.A., Domingues, I., Agra, A.R., Monaghan, K., Amadeu, M.V.M., 2010. Critical Review: Cholinesterase and glutathione-S-transferase activities in freshwater. Environ. Toxicol. Chem. 9, 518. https://doi.org/10.1002/etc.23.

Pan American Health Organization (PAHO), 2020a. WHO calls for reinvigorated action to fight malaria. OMS pede ação revigorada para combater a malária - OPAS/OMS | Organização Pan-Americana da Saúde (paho.org) (Accessed August 12, 2021).

Pan American Health Organization (PAHO), 2020b. Dengue cases in the Americas reach 1.6 million during the pandemic. Casos de dengue nas Américas chegam a 1,6 milhão, o que destaca a necessidade do controle de mosquitos durante a pandemia - OPAS/OMS | Organização Pan-Americana da Saúde (paho.org) (Accessed August 12, 2021).

Pavela, R., 2015. Acute toxicity and synergistic and antagonistic effects of the aromatic compounds of some essential oils against Culex quinquefasciatus Say larvae. Parasitol. Res. 114, 3835-3853. https://doi.org/10.1007/s00436-015-4614-9

Qin, W., Huang, S., Li, C., Chen, S., Peng, Z., 2010. Biological activity of the essential oil from the leaves of Piper sarmentosum Roxb. (Piperaceae) and its chemical constituents on Brontispa longissima (Gestro) (Coleoptera: Hispidae). Pestic. Biochem. Physiol. 96, 132-139. https://doi.org/10.1016/j.pestbp.2009.10.006

Rajkumar, S., Jebanesan, A., Nagarajan, R., 2011. Effect of leaf essential oil of Coccinia indica on egg hatchability and different larval instars of malarial mosquito Anopheles stephensi. Asian Pac. J. Trop. Med. 4, 948-951. https://doi.org/10.1016/S1995-7645(11)60224-1

Raphael, V., Borges, D.A., Ribeiro, A.F., Anselmo, C.D.S., Cabral, L.M., Sousa, V.P. De., 2013. Development of a high-performance liquid chromatography method for quantification of isomers $\beta$-caryophyllene and ahumulene in copaiba oleoresin using the Box-Behnken design. J. Chromatogra B. 940, 35-41. https://doi.org/10.1016/j.jchromb.2013.09.024

Ravi Kiran, S., Bhavani, K., Sita Devi, P., Rajeswara Rao, B.R., Janardhan Reddy, K., 2006. Composition and larvicidal activity of leaves and stem essential oils of Chloroxylon swietenia DC against Aedes aegypti and Anopheles stephensi. Bioresour. Technol. 97, 2481-2484.

https://doi.org/10.1016/j.biortech.2005.10.003

Reegan, A.D., Gandhi, M.R., Paulraj, M.G., Balakrishna, K., Ignacimuthu, S., 2014. Effect of niloticin, a protolimonoid isolated from Limonia acidissima L. (Rutaceae) on the immature stages of dengue vector Aedes aegypti L. (Diptera: Culicidae). Acta Trop. 139, 67-76. https://doi.org/10.1016/j.actatropica.2014.07.002 
Shoukat, R.F., Shakeel, M., Rizvi, S.A.H., Zafar, J., Zhang, Y., Freed, S., Xu, X., Jin, F., 2020. Larvicidal, ovicidal, synergistic, and repellent activities of Sophora alopecuroides and its dominant constituents against Aedes albopictus. Insects 11, 1-13. https://doi.org/10.3390/insects11040246

Silva, A.P., Alves, W.S., Martins, A., Tadei, W.P, Santos, J.M.M, 2014. Adaptation of a simplified bioassay to assess susceptibility status in larvae of Anopheles darlingi and Anopheles marajoara to pyrethroid deltamethrin. Brazilian Entomol. Soc. 9, 1-8. doi: 10.14295/BA.v9.139

Sivagnaname, N., Kalyanasundaram, M., 2004. Laboratory evaluation of methanolic extract of Atlantia monophylla (Family: Rutaceae) against immature stages of mosquitoes and non-target organisms, Mem. Inst. Oswaldo Cruz. 99, 115-118. doi: 10.1590/s0074-0276200400010002

Soonwera, M., Phasomkusolsi, S., 2017. Adulticidal, larvicidal, pupicidal and oviposition deterrent activities of essential oil from Zanthoxylum limonella Alston (Rutaceae) against Aedes aegypti (L.) and Culex quinquefasciatus (Say). Asian Pac. J. Trop. Biomed. 7: 967-978.

https://doi.org/10.1016/j.apjtb.2017.09.019.

Sperotto, A.R.M., Moura, D.J., Péres, V.F., Damasceno, F.C., Caramão, E.B., Henriques,

Suman, D.S., Wang, Y., Bilgrami, A.L., Gaugler, R., 2013. Activity of three insect growth regulators against Aedes and Culex mosquitoes. Acta Trop. 128, 103-109.

https://doi.org/10.1016/j.actatropica.2013.06.025

Van Den Dool H, Kratz P. D., 1963. A generalization of the retention index system including linear temperature programmed gas-liquid partition chromatography. J. Chromatogra A. 11, 463471. https://doi.org/10.1016/S0021-9673(01)80947-X

Vaz, C., Torres, R.B., Bernacci, L.C., Guimarães, E.F., Haber, L.L., Facanali, R., Vieira, M.A.R., Quecini, V., Ortiz, M., Marques, M., 2016. The chemical composition and antibacterial activity of eleven Piper species from distinct rainforest areas in Southeastern Brazil. Ind. Crops. Prod. 94, 528-539.

https://doi.org/10.1016/j.indcrop.2016.09.028

Ventorim, F., Paula, R. De, Caldeira, I., Alvarenga, A., Kelly, S., Bertolucci, V., Alves, A., Alvarenga, D., Eduardo, J., Pereira, B., 2016. Essential oil of monkey-pepper (Piper aduncum L.) cultivated under different light environments. Ind. Crops. Prod. 85, 251-257.

https://doi.org/10.1016/j.indcrop.2016.03.016

Villamizar, L.H., Cardoso, M. das G., de Andrade, J., Teixeira, M.L., Soares, M.J., 2017. Linalool, a Piper aduncum essential oil component, has selective activity against Trypanosoma cruzi trypomastigote forms at $4^{\circ}$ C. Mem. Inst. Oswaldo Cruz. 112, 131-139. https://doi.org/10.1590/0074-02760160361

Vinutha, B., Prashanth, D., Salma, K., Sreeja, S.L., Pratiti, D., Padmaja, R., Radhika, S., Amit, A., Venkateshwarlu, K., Deepak, M., 2007. Screening of selected Indian medicinal plants for 
acetylcholinesterase inhibitory activity. J. Ethnopharmacol. 109, 359-363.

https://doi.org/10.1016/j.jep.2006.06.014

World Health Organization (WHO), 1975. Manual on practical entomology in malaria. Part II. Methods and Techniques. Geneva, World Health Organization (WHO Offset Publication 13).

World Health Organization (WHO), 2005. Guidelines for laboratory and field testing of mosquito larvicides. World Health Organization Commun. Dis. Control. Prev. Erad. Who Pestic. Eval. Scheme 1-41. Ref: WHO/CDS/WHOPES/GCDPP/2005.11

World Health Organization (WHO), 2020. Word malaria report 2020: 20 years of global process \& challenges. Geneva: World Health Organization; 2020. Licence: CC BY-NC-AS 3.0 IGO.

World Health Organization (WHO), 2021. Dengue e dengue grave. Dengue e dengue grave (who.int) (Acessed august 12, 2021).

\section{Tables}

Table 1. Chemical composition of essential oil of leaves from Piper purusanum.

\begin{tabular}{|c|c|c|c|c|}
\hline Compounds & Area $(\%)^{a}$ & $\mathrm{Rl}^{\mathrm{calc}}$ & $\mathrm{Rl}^{\mathrm{lit}}$ & Identification \\
\hline Linalool & 0.52 & 1095 & 1096 & $\mathrm{RI}, \mathrm{MS}$ \\
\hline$a$-Terpineol & 1.54 & 1186 & 1188 & $\mathrm{RI}, \mathrm{MS}$ \\
\hline$\beta$-caryophyllene & 57.05 & 1419 & 1417 & $\mathrm{RI}, \mathrm{MS}$ \\
\hline$a$-Humulene & 14.50 & 1454 & 1452 & RI, MS \\
\hline$y$-Muurolene & 0.60 & 1479 & 1478 & RI, MS \\
\hline Germacrene D & 8.20 & 1481 & 1484 & RI, MS \\
\hline$\beta$-Selinene & 2.10 & 1490 & 1489 & $\mathrm{RI}, \mathrm{MS}$ \\
\hline$a$-Selinene & 4.42 & 1498 & 1500 & $\mathrm{RI}, \mathrm{MS}$ \\
\hline$\delta$-Cadinene & 2.40 & 1523 & 1525 & $\mathrm{RI}, \mathrm{MS}$ \\
\hline E-Nerolidol & 4.20 & 1563 & 1561 & $\mathrm{RI}, \mathrm{MS}$ \\
\hline Caryophyllene oxide & 3.46 & 1583 & 1552 & $\mathrm{RI}, \mathrm{MS}$ \\
\hline Eudesmol & 0.84 & 1662 & 1663 & $\mathrm{RI}, \mathrm{MS}$ \\
\hline Total of identified (\%) & 94 & & & \\
\hline
\end{tabular}

$\mathrm{R}^{\text {calc }}$ - Retention index calculated using n-alkanes (C8-C30) on the TR5 column. Rl ${ }^{\text {lit }}$ - Retention index literature (Adams 2007; NIST 2020; in-house library). ${ }^{a}$ - Relative area calculated from the peak area 
relative to the total peak area in the GC-FID chromatogram. MS - Mass spectra compared with literature (Adams 2007; NIST 2020; in-house library). Mach in percentage.

Table 2. Inhibitory activity from Piper purusanum essential oil and its main sesquiterpenes in eggs of Aedes and Anopheles eggs. 
Eggs

Concentration (ppm)

$\begin{array}{lllll}1.95 & 3.90 & 7.81 & 15.62 & 31.25\end{array}$

Essential oil

Ae. aegypti

$0.0 \pm$ $0.0^{\mathrm{a}}$

Ae. albopictus $0.0 \pm$ $0.0^{\mathrm{a}}$

$12.3 \pm 1.5^{\mathrm{b}}$

$45.6 \pm 3.0^{b}$

$72.0 \pm$ $3.0^{\mathrm{bf}}$

$63.3 \pm 5.1^{\mathrm{a}}$

$84.6 \pm 3.0^{\mathrm{a}}$

$7.6 \pm 1.5^{\mathrm{a}} \quad 20.0 \pm 2.0^{\mathrm{a}}$

$16.6 \pm 1.5^{\mathrm{c}}$

$37.3 \pm 2.5^{c}$

$88.3 \pm 2.5^{c}$

$95.6 \pm 4.5^{c}$

An. albitarsis

$0.0 \pm$ $0.0^{\mathrm{a}}$

An.

$0.0 \pm$

$12.0 \pm$

triannulatus

$0.0^{\mathrm{a}}$

$2.0^{\mathrm{db}}$

$54.3 \pm 3.0^{d} \quad 90.0 \pm 3.6^{d}$

$94.6 \pm$

An. darlingi

$0.0 \pm$

$0.0^{\mathrm{a}}$

$17.0 \pm$

$2.0^{\mathrm{ec}}$

$49.3 \pm 2.5^{\mathrm{e}}$

$96.0 \pm 4.0^{\mathrm{e}}$

$98.0 \pm 3.4^{\mathrm{e}}$

An.

$0.0 \pm$

nuneztovari

$0.0^{\mathrm{a}}$

$11.3 \pm$

$2.0^{\mathrm{fb}}$

$42.6 \pm 3.0^{f}$

$73.0 \pm 3.0^{f}$

$87.3 \pm 2.5^{f}$

$\beta$

caryophyllene
Ae. aegypti

Ae. albopictus

$0.0 \pm$

$0.0^{\mathrm{a}}$

An. albitarsis

$0.0 \pm$ $0.0^{\mathrm{a}}$

An.

triannulatus

$0.0 \pm$

$0.0^{\mathrm{a}}$

An. darlingi

$0.0 \pm$

$0.0^{\mathrm{a}}$

An.

nuneztovari

$0.0 \pm$

$0.0^{\mathrm{a}}$ $.0^{\mathrm{a}}$
$2.6 \pm 1.5^{\mathrm{a}} \quad 10.3 \pm 2.5^{\mathrm{a}}$

$25.6 \pm 4.1^{\mathrm{a}}$

$1.6 \pm 1.5^{\mathrm{b}}$

$9.3 \pm 1.5^{b}$

$34.3 \pm 3.0^{\mathrm{b}}$

$50.6 \pm 1.5^{b}$

$2.0 \pm 0.1^{\mathrm{ab}}$

$10.3 \pm 1.5^{\mathrm{a}}$

$27.6 \pm 3.2^{c}$

$48.3 \pm 3.0^{c}$

$1.3 \pm$

$1.5^{\mathrm{cbd}}$

$7.0 \pm 2.0^{c}$

$34.3 \pm$

$2.5^{\mathrm{db}}$

$0.6 \pm 0.5^{\mathrm{de}}$

$9.3 \pm 1.5^{\mathrm{db}}$

$33.3 \pm 2.5^{\mathrm{e}}$

$54.6 \pm 7.2^{\mathrm{e}}$

$1.3 \pm 1.5^{\mathrm{eb}}$

$10.6 \pm 0.2^{\mathrm{a}}$

$36.0 \pm 2.6^{f}$

$48.6 \pm$ $1.5^{\mathrm{fc}}$

\section{$a$-Humulene}

Ae. aegypti

$0.0 \pm$

$0.0^{\mathrm{a}}$

Ae. albopictus

$0.0 \pm$

$0.0^{\mathrm{a}}$

$3.6 \pm 2.5^{b}$

$2.3 \pm 2.0^{\mathrm{a}}$

$15.6 \pm 1.5^{\mathrm{a}}$

$35.6 \pm 1.5^{\mathrm{a}}$

$58.3 \pm 1.2^{\mathrm{a}}$

An. albitarsis

$0.0 \pm$ $0.0^{\mathrm{a}}$

$5.3 \pm 3.2^{\mathrm{C}}$

$16.6 \pm 0.5^{c}$

$41.3 \pm 1.4^{\mathrm{C}}$

$55.0 \pm 3.6^{c}$

An.

$0.0 \pm$

$19.3 \pm$

$35.6 \pm 1.2^{\mathrm{a}} \quad 57.6 \pm$

Page 19/29 


\begin{tabular}{llllll} 
triannulatus & $0.0^{\mathrm{a}}$ & $1.0 \pm 1.0^{\mathrm{d}}$ & $1.5^{\mathrm{db}}$ & $3.5^{\mathrm{ab}}$ \\
An. darlingi & $0.0^{\mathrm{b}} \pm$ & $5.0 \pm 2.0^{\mathrm{ec}}$ & $18.0 \pm 2.6^{\mathrm{e}}$ & $43.3 \pm 1.8^{\mathrm{d}}$ & $61.3 \pm 5.8^{\mathrm{d}}$ \\
& $0.0^{\mathrm{a}}$ & & & \\
\hline $\begin{array}{l}\text { An. } \\
\text { nuneztovari }\end{array}$ & $0.0 \pm$ & $4.3 \pm$ & $18.3 \pm$ & $36.3 \pm 2.0^{\mathrm{a}}$ & $51.0 \pm 3.6^{\mathrm{e}}$ \\
\hline
\end{tabular}

$\begin{array}{llllll}\text { Germacrene D Ae. aegypti } & \begin{array}{l}0.0 \pm \\ 0.0^{\mathrm{a}}\end{array} & 0.0 \pm 0.0^{\mathrm{a}} & 5.6 \pm 1.4^{\mathrm{a}} & 24.3 \pm 3.0^{\mathrm{a}} & 51.6 \pm 3.0^{\mathrm{a}}\end{array}$

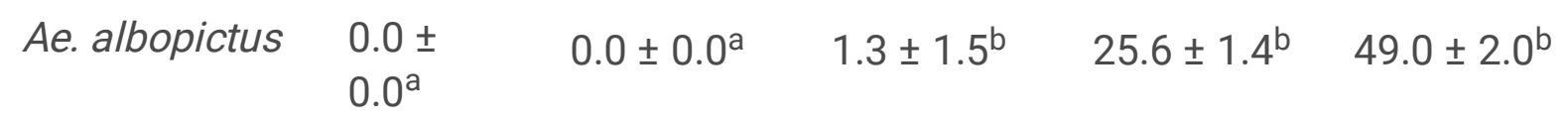

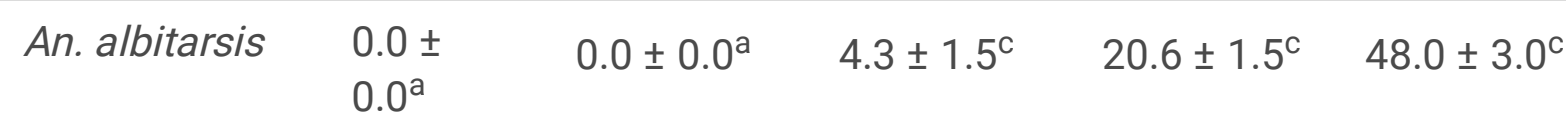

$\begin{array}{llllll}\begin{array}{l}\text { An. } \\ \text { triannulatus }\end{array} & \begin{array}{l}0.0 \pm \\ 0.0^{\mathrm{a}}\end{array} & 0.0 \pm 0.0^{\mathrm{a}} & 5.6 \pm 2.0^{\mathrm{a}} & 18.3 \pm 1.4^{\mathrm{d}} & 49.6 \pm 2.5^{\mathrm{d}} \\ & \begin{array}{l}\text { An. darlingi } \\ 0.0 \pm\end{array} & 0.0 \pm 0.0^{\mathrm{a}} & 1.3 \pm 1.5^{\mathrm{db}} & 16.0 \pm 2.6^{\mathrm{e}} & 51.3 \pm 2.0^{\mathrm{a}} \\ & 0.0^{\mathrm{a}} & & & & \end{array}$

\begin{tabular}{|c|c|}
\hline $\begin{array}{l}\text { An. } \\
\text { nuneztovari }\end{array}$ & $\begin{array}{l}0.0 \pm \\
0.0^{\mathrm{a}}\end{array}$ \\
\hline
\end{tabular}

Temephos

\begin{tabular}{|c|c|c|c|c|c|}
\hline Ae. aegypti & $\begin{array}{l}0.0 \pm \\
0.0^{\mathrm{a}}\end{array}$ & $11.0 \pm 2^{\mathrm{a}}$ & $20.9 \pm 1.0^{\mathrm{a}}$ & $39.0 \pm 2.2^{\mathrm{a}}$ & $49.1 \pm 2.4^{a}$ \\
\hline Ae. albopictus & $\begin{array}{l}0.0 \pm \\
0.0^{\mathrm{a}}\end{array}$ & $9.2 \pm 1.1^{b}$ & $15.1 \pm 2.2^{b}$ & $32.3 \pm 3.2^{b}$ & $49.6 \pm 1.5^{a}$ \\
\hline An. albitarsis & $\begin{array}{l}0.0 \pm \\
0.0^{\mathrm{a}}\end{array}$ & $11.5 \pm 2.4^{\mathrm{a}}$ & $17.0 \pm 3.0^{c}$ & $44.0 \pm 2.4^{c}$ & $56.0 \pm 2.6^{b}$ \\
\hline $\begin{array}{l}\text { An. } \\
\text { triannulatus }\end{array}$ & $\begin{array}{l}0.0 \pm \\
0.0^{\mathrm{a}}\end{array}$ & $13.0 \pm 2.2^{c}$ & $19.0 \pm 3.0^{d}$ & $34.1 \pm 2.1^{d}$ & $57.0 \pm 1.1^{\mathrm{c}}$ \\
\hline An. darlingi & $\begin{array}{l}0.0 \pm \\
0.0^{\mathrm{a}}\end{array}$ & $7.0 \pm 2.1^{d}$ & $\begin{array}{l}15.1 \pm \\
1.1^{\mathrm{eb}}\end{array}$ & $37.0 \pm 3.2^{\mathrm{e}}$ & $46.0 \pm 1.1^{d}$ \\
\hline $\begin{array}{l}\text { An. } \\
\text { nuneztovari }\end{array}$ & $\begin{array}{l}0.0 \pm \\
0.0^{\mathrm{a}}\end{array}$ & $\begin{array}{l}12.5 \pm \\
3.0^{\mathrm{ec}}\end{array}$ & $\begin{array}{l}19.0 \pm \\
3.0^{\mathrm{fd}}\end{array}$ & $\begin{array}{l}34.0 \pm \\
3.2^{\mathrm{fd}}\end{array}$ & $44.0 \pm 1.7 \mathrm{e}$ \\
\hline
\end{tabular}

Each value represents the mean of five replicates \pm SD. Values carrying different letters in each column are statistical differences by ANOVA Tukey's test $p<0.05$. The negative control ( 1.95 to $31.25 \mathrm{ppm}$ ) presented eggs hatched from $97.5 \pm 2.1$ to $100 \pm 0.0 \%$. 
Table 3. Larvicidal activity of essential oil from Piper purusanum and its main sesquiterpenes in Anopheles larvae. 


\begin{tabular}{|c|c|c|c|c|c|}
\hline & Larvae & $\begin{array}{l}\mathrm{LC}_{50}(\mathrm{ppm})(\mathrm{LCL}- \\
\mathrm{UCL})\end{array}$ & $\begin{array}{l}\mathrm{LC}_{90}(\mathrm{ppm})(\mathrm{LCL}- \\
\mathrm{UCL})\end{array}$ & $\chi^{2}(\mathrm{Df})$ & $\begin{array}{l}\text { Slope } \pm \\
\text { SE }\end{array}$ \\
\hline \multirow[t]{4}{*}{ Essential oil } & $\begin{array}{l}\text { An. } \\
\text { nuneztovari }\end{array}$ & $\begin{array}{l}51.60^{\mathrm{a}}(40.769- \\
61.806)\end{array}$ & $\begin{array}{l}101.17 \text { (82.016- } \\
146.279)\end{array}$ & 7.1(3) & $\begin{array}{l}4.383 \pm \\
0.331\end{array}$ \\
\hline & $\begin{array}{l}\text { An. } \\
\text { triannulatus }\end{array}$ & $\begin{array}{l}51.61^{\mathrm{a}}(43.164- \\
59.634)\end{array}$ & $\begin{array}{l}96.07 \text { (81.187- } \\
124.824)\end{array}$ & $5.0(3)$ & $\begin{array}{l}4.750 \pm \\
0.353\end{array}$ \\
\hline & An. darlingi & $\begin{array}{l}49.84^{\mathrm{a}}(42.553- \\
56.776)\end{array}$ & $\begin{array}{l}91.82(78.902- \\
114.696)\end{array}$ & $4.2(3)$ & $\begin{array}{l}4.830 \pm \\
0.357\end{array}$ \\
\hline & An. albitarsis & $\begin{array}{l}50.05^{\mathrm{a}}(38.915- \\
60.469)\end{array}$ & $\begin{array}{l}100.91(81.039- \\
149.314)\end{array}$ & 7.2(3) & $\begin{array}{l}4.209 \pm \\
0.321\end{array}$ \\
\hline \multirow[t]{4}{*}{$\begin{array}{l}\beta \\
\text { caryophyllene }\end{array}$} & $\begin{array}{l}\text { An. } \\
\text { nuneztovari }\end{array}$ & $\begin{array}{l}28.86^{\mathrm{a}}(24.548- \\
33.350)\end{array}$ & $51.82(42.994-3.001)$ & $5.9(3)$ & $\begin{array}{l}5.041 \pm \\
0.404\end{array}$ \\
\hline & $\begin{array}{l}\text { An. } \\
\text { triannulatus }\end{array}$ & $\begin{array}{l}26.52^{\mathrm{a}}(24.831- \\
28.197)\end{array}$ & $\begin{array}{l}46.51(42.770- \\
51.738\end{array}$ & $0.6(3)$ & $\begin{array}{l}5.253 \pm \\
0.412\end{array}$ \\
\hline & An. darlingi & $\begin{array}{l}25.14^{\mathrm{a}}(23.172- \\
27.158)\end{array}$ & $\begin{array}{l}54.73(48.603- \\
63.868)\end{array}$ & 2.8(3) & $\begin{array}{l}3.794 \pm \\
0.308\end{array}$ \\
\hline & An. albitarsis & $\begin{array}{l}26.36^{\mathrm{a}}(24.437- \\
28.336)\end{array}$ & $\begin{array}{l}53.92(48.308- \\
62.182)\end{array}$ & $0.6(3)$ & $\begin{array}{l}4.124 \pm \\
0.331\end{array}$ \\
\hline \multirow[t]{4}{*}{$\alpha$-Humulene } & $\begin{array}{l}\text { An. } \\
\text { nuneztovari }\end{array}$ & $\begin{array}{l}26.63^{\mathrm{a}}(24.832- \\
28.423)\end{array}$ & $\begin{array}{l}49.56(45.135- \\
55.885)\end{array}$ & $0.3(3)$ & $\begin{array}{l}4.749 \pm \\
0.378\end{array}$ \\
\hline & $\begin{array}{l}\text { An. } \\
\text { triannulatus }\end{array}$ & $\begin{array}{l}33.08^{\mathrm{b}}(31.010- \\
35.315)\end{array}$ & $\begin{array}{l}61.41(54.978- \\
71.371)\end{array}$ & $0.2(3)$ & $\begin{array}{l}4.769 \pm \\
0.424\end{array}$ \\
\hline & An. darlingi & $\begin{array}{l}30.36^{\mathrm{ab}}(28.020- \\
32.936)\end{array}$ & $\begin{array}{l}68.88(59.600- \\
83.958)\end{array}$ & $0.4(3)$ & $\begin{array}{l}3.602 \pm \\
0.323\end{array}$ \\
\hline & An. albitarsis & $\begin{array}{l}37.42^{c}(34.558- \\
40.982)\end{array}$ & $\begin{array}{l}82.58(69.875- \\
104.840)\end{array}$ & $2.0(3)$ & $\begin{array}{l}3.729 \pm \\
0.365\end{array}$ \\
\hline \multirow[t]{3}{*}{$\begin{array}{l}\text { Germacrene } \\
\text { D }\end{array}$} & $\begin{array}{l}\text { An. } \\
\text { nuneztovari }\end{array}$ & $\begin{array}{l}32.36^{\mathrm{a}}(30.378- \\
34.459)\end{array}$ & $\begin{array}{l}58.68(52.910- \\
67.430)\end{array}$ & $0.4(3)$ & $\begin{array}{l}4.958 \pm \\
0.432\end{array}$ \\
\hline & $\begin{array}{l}\text { An. } \\
\text { triannulatus }\end{array}$ & $\begin{array}{l}30.31^{\mathrm{a}}(28.294- \\
32.424)\end{array}$ & $\begin{array}{l}58.53(52.427- \\
67.784)\end{array}$ & $0.3(3)$ & $\begin{array}{l}4.485 \pm \\
0.385\end{array}$ \\
\hline & An. darlingi & $\begin{array}{l}24.49^{b}(22.803- \\
26.165)\end{array}$ & $\begin{array}{l}45.11(41.294- \\
50.407)\end{array}$ & $0.1(3)$ & $\begin{array}{l}4.833 \pm \\
0.372\end{array}$ \\
\hline
\end{tabular}




\begin{tabular}{|c|c|c|c|c|c|}
\hline Temephos & $\begin{array}{l}\text { An. } \\
\text { nuneztovari }\end{array}$ & $3.93^{\mathrm{a}}(3.401-4.509)$ & $\begin{array}{l}14.29(11.810- \\
18.178)\end{array}$ & $0.2(3)$ & $\begin{array}{l}2.287 \pm \\
0.174\end{array}$ \\
\hline & $\begin{array}{l}\text { An. } \\
\text { triannulatus }\end{array}$ & $3.85^{\mathrm{a}}(3.371-4.369)$ & $\begin{array}{l}11.95(10.085- \\
14.785)\end{array}$ & $0.1(3)$ & $\begin{array}{l}2.606 \pm \\
0.196\end{array}$ \\
\hline & An. darlingi & $5.21^{\mathrm{b}}(4.644-5.828)$ & $\begin{array}{l}13.71(11.750- \\
16.676)\end{array}$ & $0.2(3)$ & $\begin{array}{l}3.050 \pm \\
0.234\end{array}$ \\
\hline & An. albitarsis & $5.45^{\mathrm{b}}(4.787-6.182)$ & $\begin{array}{l}17.72(14.736- \\
22.382)\end{array}$ & $0.4(3)$ & $\begin{array}{l}2.503 \pm \\
0.189\end{array}$ \\
\hline
\end{tabular}

$\mathrm{LC}_{50}$ and $\mathrm{LC}_{90}$ - Concentrations needed to kill $50 \%$ and $90 \%$ of larvae. $\mathrm{LCL}$ - Lower confidence limit of $95 \%$. UCL - Upper confidence limit of $95 \% . \chi^{2}-p<0.05$. level of significance of Chi-square value. Df Degree of freedom. Letters in the same column indicate statistical differences (ANOVA and Tukey $p<$ 0.05). No mortality was observed in the negative control.

Table 4. Larvicidal activity of essential oil from Piper purusanum and its main sesquiterpenes in Aedes larvae. 


\begin{tabular}{|c|c|c|c|c|c|}
\hline & Larvae & $\begin{array}{l}\mathrm{LC}_{50}(\mathrm{ppm})(\mathrm{LCL}- \\
\mathrm{UCL})\end{array}$ & $\begin{array}{l}\mathrm{LC}_{90}(\mathrm{ppm})(\mathrm{LCL}- \\
\mathrm{UCL})\end{array}$ & $\chi^{2}(D f)$ & Slope \pm SE \\
\hline \multirow[t]{2}{*}{ Essential oil } & Ae. aegypti & $\begin{array}{l}53.41^{b}(49.773- \\
56.940)\end{array}$ & $\begin{array}{l}91.01(84.285- \\
99.953)\end{array}$ & $2.8(3)$ & $\begin{array}{l}5.536 \pm \\
0.414\end{array}$ \\
\hline & $\begin{array}{l}\text { Ae. } \\
\text { albopictus }\end{array}$ & $\begin{array}{l}42.62^{\mathrm{a}}(34.627- \\
49.929)\end{array}$ & $\begin{array}{l}88.63(74.059- \\
116.525)\end{array}$ & $4.3(3)$ & $\begin{array}{l}4.030 \pm \\
0.315\end{array}$ \\
\hline \multirow[t]{2}{*}{$\begin{array}{l}\beta \\
\text { caryophyllene }\end{array}$} & Ae. aegypti & $\begin{array}{l}29.97^{\mathrm{a}}(28.313- \\
31.611)\end{array}$ & $\begin{array}{l}48.34(44.802- \\
53.356)\end{array}$ & $0.2(3)$ & $6.170+-0.512$ \\
\hline & $\begin{array}{l}\text { Ae. } \\
\text { albopictus }\end{array}$ & $\begin{array}{l}31.09^{b}(29.218- \\
33.021)\end{array}$ & $\begin{array}{l}54.92(49.942 \text { to } \\
62.313)\end{array}$ & $0.7(3)$ & $5.187+-0.447$ \\
\hline \multirow[t]{2}{*}{$\alpha$-Humulene } & Ae. aegypti & $\begin{array}{l}28.11^{\mathrm{a}}(26.301- \\
29.940)\end{array}$ & $\begin{array}{l}51.100(46.568- \\
57.626)\end{array}$ & $0.1(3)$ & $\begin{array}{l}4.940 \pm \\
0.403\end{array}$ \\
\hline & $\begin{array}{l}\text { Ae. } \\
\text { albopictus }\end{array}$ & $\begin{array}{l}28.89^{b}(27.199- \\
30.570)\end{array}$ & $\begin{array}{l}48.28(44.556- \\
53.554)\end{array}$ & $0.5(3)$ & $\begin{array}{l}5.748 \pm \\
0.474\end{array}$ \\
\hline \multirow[t]{2}{*}{$\begin{array}{l}\text { Germacrene } \\
\text { D }\end{array}$} & Ae. aegypti & $\begin{array}{l}35.96^{\mathrm{b}}(33.953- \\
38.183)\end{array}$ & $\begin{array}{l}61.46(55.474- \\
70.817)\end{array}$ & $0.1(3)$ & $\begin{array}{l}5.507 \pm \\
0.513\end{array}$ \\
\hline & $\begin{array}{l}\text { Ae. } \\
\text { albopictus }\end{array}$ & $\begin{array}{l}33.51^{\mathrm{a}}(31.270- \\
36.014)\end{array}$ & $\begin{array}{l}66.43(58.534- \\
79.065)\end{array}$ & $0.0(3)$ & $\begin{array}{l}4.313 \pm \\
0.393\end{array}$ \\
\hline \multirow[t]{2}{*}{ Temephos } & Ae. aegypti & $\begin{array}{l}3.21^{b}(2.936- \\
3.529)\end{array}$ & $6.63(5.833-7.797)$ & $2.8(3)$ & $\begin{array}{l}4.082 \pm \\
0.312\end{array}$ \\
\hline & $\begin{array}{l}\text { Ae. } \\
\text { albopictus }\end{array}$ & $\begin{array}{l}2.75^{\mathrm{a}}(2.210- \\
3.440)\end{array}$ & $5.25(4.069-8.442)$ & $6.4(3)$ & $\begin{array}{l}4.560 \pm \\
0.368\end{array}$ \\
\hline
\end{tabular}

LC $_{50}$ and 90 - Concentrations needed to kill $50 \%$ and $90 \%$ of larvae. LCL - Lower confidence limit of $95 \%$. UCL - Upper confidence limit of $95 \%$. $\chi^{2}$ - Non significant Chi-square $(p<0.05)$. Df - Degree of freedom. Letters in the same column indicate statistical differences (ANOVA and Tukey $p<0.05$ ). No mortality was observed in the negative control.

Table 5. Toxicity of essential oil from Piper purusanum and its main sesquiterpenes in non-target predators. 
Predators $\quad \mathrm{LC}_{50}(\mathrm{ppm}) \quad \mathrm{LC}_{90}(\mathrm{ppm})(\mathrm{LCL}-\mathrm{UCL}) \quad \chi^{2}(\mathrm{Df}) \quad$ Slope $\pm \mathrm{SE}$ (LCL-UCL)

\begin{tabular}{|c|c|c|c|c|c|}
\hline Essential oil & $\begin{array}{l}\text { A. } \\
\text { bouvieri }\end{array}$ & $\begin{array}{l}7707.13^{\mathrm{a}} \\
(3950.840- \\
135645.468)\end{array}$ & $\begin{array}{l}24903.72 \\
(8183.569-3183691.715)\end{array}$ & $1.48(5)$ & $2.516 \pm 0.808$ \\
\hline & $\begin{array}{l}\text { T. } \\
\text { splendens }\end{array}$ & $\begin{array}{l}4967.50^{\mathrm{b}} \\
(3203.262- \\
23203.605)\end{array}$ & $\begin{array}{l}11633.046(5555.462- \\
164614.729)\end{array}$ & $0.40(5)$ & $3.468 \pm 1.004$ \\
\hline & G. affinis & $\begin{array}{l}7465.93^{c} \\
(3776.745- \\
27751.616)\end{array}$ & $\begin{array}{l}21659.25 \text { (7120.796- } \\
11450761.325)\end{array}$ & $0.64(5)$ & $2.771 \pm 0.991$ \\
\hline & D. indicus & $\begin{array}{l}2506.56^{d} \\
(1957.622- \\
5873.229)\end{array}$ & $\begin{array}{l}4313.126(2786.461- \\
20242.556)\end{array}$ & $0.40(5)$ & $5.437 \pm 1.563$ \\
\hline
\end{tabular}

\begin{tabular}{|c|c|c|c|c|c|}
\hline $\begin{array}{l}\beta- \\
\text { caryophyllene }\end{array}$ & $\begin{array}{l}\text { A. } \\
\text { bouvieri }\end{array}$ & $\begin{array}{l}6335.83^{\mathrm{a}} \\
(3830.667- \\
21592.921)\end{array}$ & $\begin{array}{l}26409.50(10510.022- \\
260590.887)\end{array}$ & $2.57(5)$ & $2.067 \pm 0.453$ \\
\hline & $\begin{array}{l}\text { T. } \\
\text { splendens }\end{array}$ & $\begin{array}{l}4418.14^{\mathrm{b}} \\
(3097.966- \\
10330.971)\end{array}$ & $\begin{array}{l}11823.55(6239.198- \\
56593.581)\end{array}$ & $2.69(5)$ & $2.998 \pm 0.649$ \\
\hline & G. affinis & $\begin{array}{l}5424.84^{c} \\
(3313.846- \\
38027.706)\end{array}$ & $\begin{array}{l}13344.40(5850.323- \\
368884.286)\end{array}$ & $3.11(5)$ & $3.278 \pm 1.012$ \\
\hline & D. indicus & $\begin{array}{l}4524.95^{d} \\
(3144.723- \\
10631.760)\end{array}$ & $\begin{array}{l}12826.59(6624.054- \\
62749.488)\end{array}$ & $3.93(5)$ & $2.832 \pm 0.601$ \\
\hline
\end{tabular}

\begin{tabular}{|c|c|c|c|c|c|}
\hline$a$-Humulene & $\begin{array}{l}\text { A. } \\
\text { bouvieri }\end{array}$ & $\begin{array}{l}5534.53^{\mathrm{a}} \\
(3557.791- \\
14876.619)\end{array}$ & $\begin{array}{l}22826.33(9934.008- \\
153027.914)\end{array}$ & $4.59(5)$ & $2.083 \pm 0.420$ \\
\hline & $\begin{array}{l}\text { T. } \\
\text { splendens }\end{array}$ & $\begin{array}{l}4162.19^{\mathrm{b}} \\
(3003.536- \\
8489.781)\end{array}$ & $\begin{array}{l}11673.61(6378.430- \\
45232.403)\end{array}$ & $4.95(5)$ & $2.861 \pm 0.565$ \\
\hline & G. affinis & $\begin{array}{l}6082.02^{\mathrm{C}} \\
(3649.216- \\
27140.183)\end{array}$ & $\begin{array}{l}\text { 19492.24 (7999.169- } \\
277482.167)\end{array}$ & $3.34(5)$ & $2.534 \pm 0.648$ \\
\hline & D. indicus & $\begin{array}{l}2386.94^{\mathrm{d}} \\
(1938.517- \\
3905.869)\end{array}$ & $\begin{array}{l}4678.51(3132.171- \\
12403.013)\end{array}$ & $4.45(5)$ & $4.385 \pm 0.941$ \\
\hline
\end{tabular}




\begin{tabular}{|c|c|c|c|c|c|}
\hline $\begin{array}{l}\text { Germacrene } \\
\text { D }\end{array}$ & $\begin{array}{l}\text { A. } \\
\text { bouvieri }\end{array}$ & $\begin{array}{l}5429.94^{\mathrm{a}} \\
(3522.213- \\
14125.298)\end{array}$ & $\begin{array}{l}22253.293(9828.860- \\
140883.873)\end{array}$ & $3.76(5)$ & $2.092 \pm 0.416$ \\
\hline & $\begin{array}{l}\text { T. } \\
\text { splendens }\end{array}$ & $\begin{array}{l}3926.30^{\mathrm{b}} \\
(2541.030- \\
20317.147)\end{array}$ & $\begin{array}{l}11435.69(5040.302- \\
292789.666)\end{array}$ & $8.15(5)$ & $2.760 \pm 0.506$ \\
\hline & G. affinis & $\begin{array}{l}4439.74^{\mathrm{C}} \\
(3112.705- \\
10045.497)\end{array}$ & $\begin{array}{l}12658.45(6613.556- \\
58371.571)\end{array}$ & $4.58(5)$ & $2.816 \pm 0.586$ \\
\hline & D. indicus & $\begin{array}{l}2098.80^{d} \\
(1713.703- \\
5700.298)\end{array}$ & $\begin{array}{l}3255.529(2240.195- \\
22069.924)\end{array}$ & $5.83(5)$ & $6.722 \pm 1.639$ \\
\hline
\end{tabular}

\begin{tabular}{llllll}
\hline Temephos & $\begin{array}{l}\text { A. } \\
\text { bouvieri }\end{array}$ & $\begin{array}{l}4.99^{\mathrm{a}}(4.534- \\
5.510)\end{array}$ & $10.93(9.494-13.085)$ & $0.15(3)$ & $3.767 \pm 0.292$ \\
\hline $\begin{array}{l}\text { s. } \\
\text { splendens }\end{array}$ & $\begin{array}{l}4.85^{\mathrm{b}}(4.443- \\
5.312)\end{array}$ & $9.50(8.399-11.137)$ & $0.33(3)$ & $4.394 \pm 0.352$ \\
& G. affinis & $\begin{array}{l}5.81^{\mathrm{c}}(5.373- \\
6.283)\end{array}$ & $9.71(8.744-11.145)$ & $0.07(3)$ & $5.743 \pm 0.513$ \\
& & & & \\
\hline D. indicus & $\begin{array}{l}5.82^{\mathrm{c}}(4.869- \\
7.057)\end{array}$ & $12.35(9.668-18.528)$ & $3.93(3)$ & $3.925 \pm 0.322$ \\
& & & &
\end{tabular}

$\mathrm{LC}_{50}$ and $\mathrm{LC}_{90}$ - Concentrations needed to kill $50 \%$ and $90 \%$ of larvae. $\mathrm{LCL}$ - Lower confidence limit of $95 \%$. UCL - Upper confidence limit of $95 \% . \chi^{2}$ - Non significant Chi-square $(p<0.05)$. Df - Degree of freedom. Letters in the same column indicate statistical differences (ANOVA and Tukey $p<0.05$ ). No mortality was observed in the control.

Table 6. Suitability index / Predator Safety Factor in different predators exposed to the essential oil of Piper purusanum and its sesquiterpenes in Anopheles larvae 


\begin{tabular}{|c|c|c|c|c|c|}
\hline & Predators & An. nuneztovari & An. triannulatus & An. darlingi & An. albitarsis \\
\hline \multirow[t]{4}{*}{ Essential oil } & A. bouvieri & 149.36 & 149.33 & 154.63 & 153.98 \\
\hline & T. splendens & 96.26 & 96.25 & 99.66 & 99.25 \\
\hline & G. affinis & 144.68 & 144.66 & 149.79 & 149.16 \\
\hline & D. indicus & 48.57 & 48.56 & 50.29 & 50.08 \\
\hline \multirow[t]{4}{*}{$\beta$-caryophyllene } & A. bouvieri & 219.53 & 238.90 & 252.02 & 240.35 \\
\hline & T. splendens & 153.08 & 166.59 & 175.74 & 167.60 \\
\hline & G. affinis & 187.97 & 204.55 & 215.78 & 205.79 \\
\hline & D. indicus & 156.78 & 170.62 & 179.99 & 171.65 \\
\hline \multirow[t]{4}{*}{$\alpha$-Humulene } & A. bouvieri & 207.83 & 167.30 & 182.29 & 147.90 \\
\hline & T. splendens & 156.29 & 125.82 & 137.09 & 111.22 \\
\hline & G. affinis & 228.38 & 183.85 & 200.33 & 162.53 \\
\hline & D. indicus & 83.63 & 72.15 & 78.62 & 63.78 \\
\hline \multirow[t]{4}{*}{ Germacrene D } & A. bouvieri & 167.79 & 179.14 & 221.72 & 173.92 \\
\hline & T. splendens & 121.33 & 129.53 & 160.32 & 125.76 \\
\hline & G. affinis & 137.19 & 146.47 & 181.28 & 142.20 \\
\hline & D. indicus & 64.85 & 69.24 & 85.70 & 67.22 \\
\hline \multirow[t]{4}{*}{ Temephos } & A. bouvieri & 1.26 & 1.29 & 0.95 & 1.12 \\
\hline & T. splendens & 1.23 & 1.25 & 0.93 & 0.88 \\
\hline & G. affinis & 1.47 & 1.50 & 1.11 & 1.06 \\
\hline & D. indicus & 1.48 & 1.51 & 1.11 & 1.06 \\
\hline
\end{tabular}

Table 7. Suitability Index / Predator Safety Factor in different predators exposed to the essential oil from Piper purusanum and its sesquiterpenes in larvae of Aedes. 


\begin{tabular}{llll} 
& Predators & Ae. aegypti & Ae. albopictus \\
\hline Essential oil & A. bouvieri & 144.30 & 180.83 \\
\hline T. splendens & 93.00 & 116.55 \\
\hline G. affinis & 139.78 & 175.17 \\
\hline D. indicus & 46.93 & 58.81
\end{tabular}

\begin{tabular}{cccc}
\hline B-caryophyllene & A. bouvieri & 211.40 & 203.78 \\
\hline T. splendens & 147.41 & 142.10 \\
\hline G. affinis & 180.98 & 174.46 \\
\hline D. indicus & 150.98 & 145.54
\end{tabular}

\begin{tabular}{cccc}
\hline a-Humulene & A. bouvieri & 196.88 & 191.57 \\
\hline T. splendens & 148.06 & 144.07 \\
\hline G. affinis & 216.36 & 210.53 \\
\hline D. indicus & 84.91 & 82.62 \\
\hline
\end{tabular}

\begin{tabular}{|c|c|c|c|}
\hline \multirow[t]{4}{*}{ Germacrene D } & A. bouvieri & 146.91 & 162.03 \\
\hline & T. splendens & 109.18 & 117.16 \\
\hline & G. affinis & 123.46 & 132.49 \\
\hline & D. indicus & 58.36 & 62.63 \\
\hline
\end{tabular}

\begin{tabular}{llll}
\hline Temephos & A. bouvieri & 1.55 & 1.81 \\
\hline T. splendens & 1.51 & 1.76 \\
\hline G. affinis & 1.80 & 2.11 \\
\hline D. indicus & 1.81 & 2.11
\end{tabular}

Table 8. Acetylcholinesterase activity of the essential oil from Piper purusanum and its main sesquiterpenes. 


\begin{tabular}{lll} 
& $\mathrm{IC}_{50}(\mathrm{ppm})$ & $r^{2}$ \\
\hline Essential oil & $2.29^{\mathrm{b}}(1.562-2.266)^{*}$ & 0.9806 \\
\hline$\beta$-caryophyllene & $5.37^{\mathrm{d}}(3.548-8.728)^{\star}$ & 0.9745 \\
\hline$a$-Humulene & $4.36^{\mathrm{c}}(2.809-7.172)^{\star}$ & 0.9711 \\
\hline Germacrene D & $10.91^{\mathrm{e}}(7.901-16.040)^{\star}$ & 0.9670 \\
\hline Neostigmine & $0.77^{\mathrm{a}}(0.596-1.022)^{*}$ & 0.9950
\end{tabular}

${ }^{*}$ Confidence limit of $95 \%$. Letters in the same column indicate statistical differences (ANOVA and Tukey $p<0.05) . r^{2}-$ Linear regression.

\section{Figures}

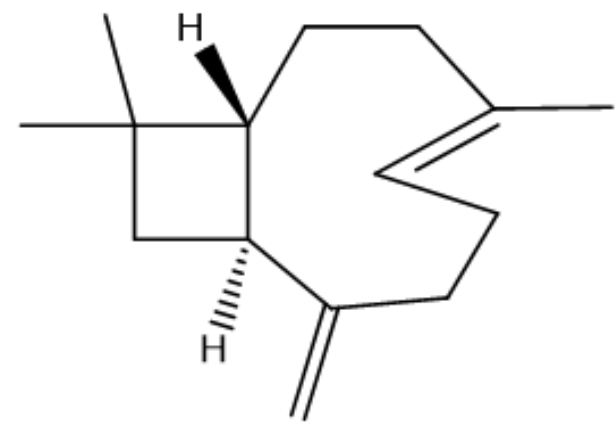

ß-Caryophyllene

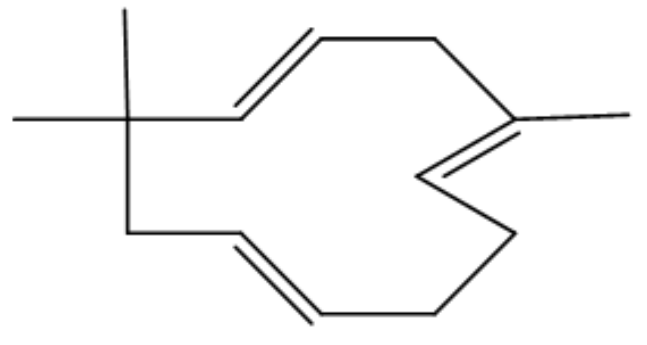

$\alpha$-Humulene

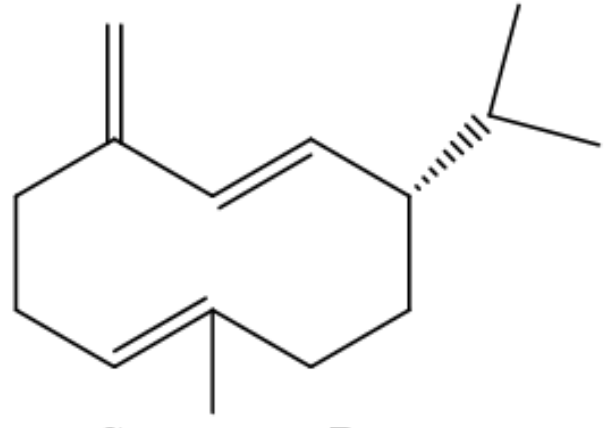

Germacreno D

\section{Figure 1}

The major sesquiterpenes of essential oil of Piper purusanum (ChemBioDraw Ultra). 